\title{
WINTER 2016
}

\section{The}

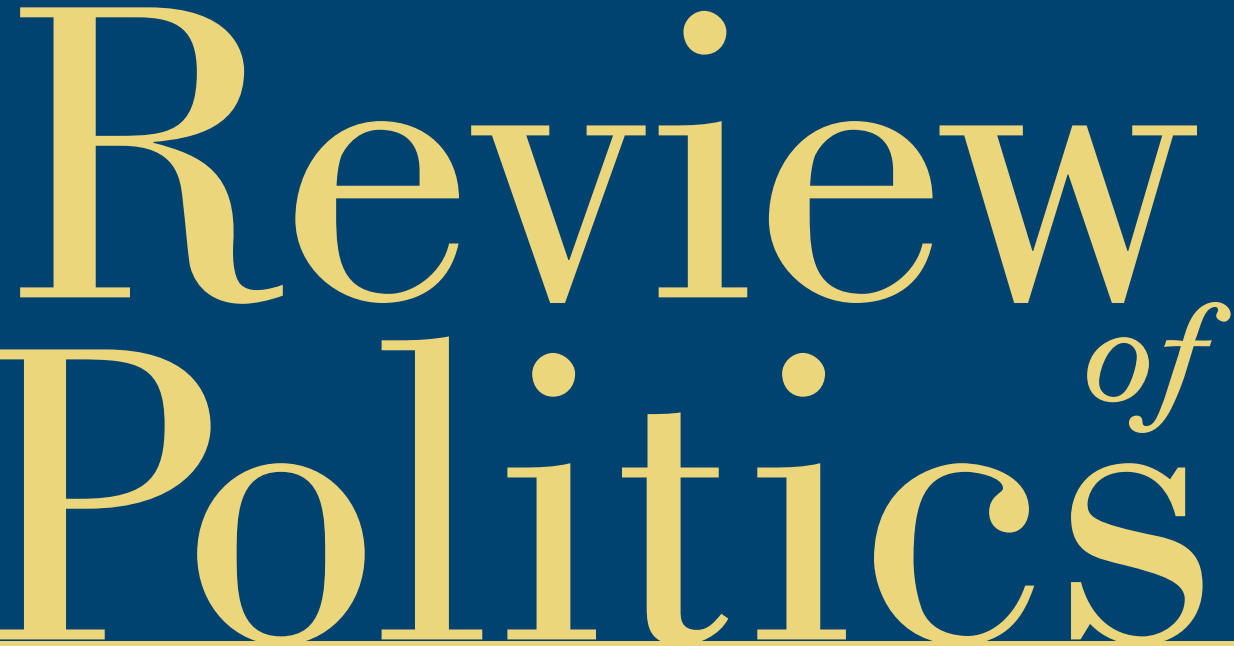

ARTICLES

Teresa M. Bejan, "Difference without Disagreement:

Rethinking Hobbes on 'Independency'

and Toleration"

Vicki Hsueh, "Intoxicated Reasons, Rational Feelings:

Rethinking the Early Modern English

Public Sphere"

Joshua L. Cherniss, "A Tempered Liberalism: Political Ethics and Ethos in Reinhold Niebuhr's Thought"

Sonia Sikka, "On Translating Religious Reasons: Rawls, Habermas, and the Quest for a Neutral Public Sphere"

John M. Warner and James R. Zink, "Therapeutic Politics:

Rawls's Respect for Rousseau" 


\title{
THE REVIEW OF POLITICS
}

\author{
Editor \\ CATHERINE H. ZUCKERT \\ Executive Associate Editor \\ DENNIS WM MORAN \\ Book Review Editor \\ RUTH ABBEY
}

Editorial Board

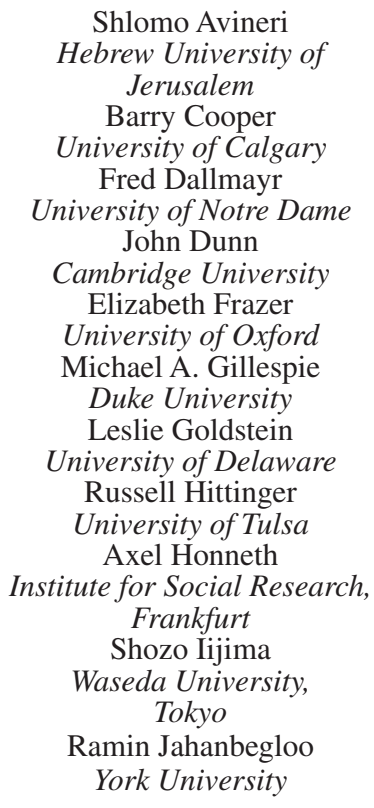

\author{
Pierre Manent \\ L'Ecole des Hautes Etudes en \\ sciences sociales \\ Harvey C. Mansfield \\ Harvard University \\ Mary Nichols \\ Baylor University \\ Daniel Philpott \\ University of Notre Dame \\ Arlene Saxonhouse \\ University of Michigan \\ William E. Scheuerman \\ Indiana University, Bloomington \\ Steven B. Smith \\ Yale University \\ Peter Steinberger \\ Reed College \\ Vickie Sullivan \\ Tufts University \\ Jean M. Yarbrough \\ Bowdoin College
}

\section{Copyeditor: LES HARRIS}

Editorial Interns: Catherine Sims and Jakub Voboril Administrative Assistant: Kelli Brown

\section{Former Editors}

\begin{abstract}
Waldemar Gurian
M.A. Fitzsimons

Thomas Stritch
\end{abstract}

\author{
Frederick J. Crosson \\ Donald P. Kommers \\ Walter Nicgorski
}

The Review of Politics publishes primarily philosophical and historical studies of politics, especially those in political theory and American political thought. The journal also includes thoughtful scholarly reflections on all aspects of politics-laws, and institutions, international relations, comparative politics-as well as literary reflections on politics or political interpretations of literature. 


\section{TABLE OF CONTENTS WINTER 2016}

Vol. 78

WINTER 2016

No. 1

Teresa M. Bejan

Difference without Disagreement: Rethinking Hobbes on

"Independency" and Toleration $\ldots \ldots \ldots \ldots \ldots \ldots \ldots$

Vicki Hsueh

Intoxicated Reasons, Rational Feelings: Rethinking the Early

Modern English Public Sphere . . . . . . . . . . . . . . 27

Joshua L. Cherniss

A Tempered Liberalism: Political Ethics and Ethos in Reinhold

Niebuhr's Thought ...................... 59

Sonia Sikka

On Translating Religious Reasons: Rawls, Habermas, and the

Quest for a Neutral Public Sphere .............. 91

John M. Warner and James R. Zink

Therapeutic Politics: Rawls's Respect for Rousseau . . . . . . 117

Review Essay:

Elizabeth Frazer

Violence and Civility

Reviews:

Clifford Ando

Review of Jordan Branch's The Cartographic State: Maps, Territory, and the

Origins of Sovereignty. . . . . . . . . . . . . . . . . . . . . . 147

Ann W. Astell

Review of Antonio Calcagno's Lived Experience from the Inside Out. Social and Political Philosophy in Edith Stein . . . . . . . . . . . . . . . . . 149

Tony Burns

Review of Melissa Lane's The Birth of Politics: Eight Greek and Roman

Political Ideas and Why They Matter . . . . . . . . . . . . . . . . . . . . 152

Henry C. Clark

Review of Hilary Gatti's Ideas of Liberty in Early Modern Europe: From

Machiavelli to Milton . . . . . . . . . . . . . . . . . . . . . . 155

Michelle T. Clarke

Review of Jan H. Blits's The Heart of Rome: Ancient Rome's Political

Culture. . . . . . . . . . . . . . . . . . . . . . . . . . . . . . . 157

Julie E. Cooper

Review of Alan L. Mittleman's Human Nature and Jewish Thought:

Judaism's Case for Why Humans Matter. 
Stefan Dolgert

Review of Peter J. Ahrensdorf's Homer on the Gods and Human Virtue:

Creating the Foundations of Classical Civilization . . . . . . . . . . . 163

Rebecca McCumbers Flavin

Review of Eric T. Kasper and Troy A. Kozma's Machiavelli Goes to the

Movies: Understanding "The Prince" through Television and Film . . . . . 165

Clara Sandelind

Review of Oliviero Angeli's Cosmopolitanism, Self-Determination and Territory: Justice with Borders . . . . . . . . . . . . . . . . . . . 168

Carla Yumatle

Review of Jacob T. Levy's Rationalism, Pluralism, and Freedom . . . . . 170 John Zumbrunnen

Review of Mary P. Nichols's Thucydides and the Pursuit of Freedom . . 174 
Subscription Information: The Review of Politics (ISSN 0034-6705) is published quarterly in February, May, August and November by Cambridge University Press, 32 Avenue of the Americas, New York, NY 10013-2473 USA/University Printing House, Shaftesbury Road, Cambridge CB2 8BS, UK for the University of Notre Dame. Annual subscription rates for Volume 78 (2016): Institutional subscription rates, print and online: US $\$ 192.00$ in the USA, Canada, and Mexico; UK $£ 112.00$ + VAT elsewhere. Institutional subscription rates, online only: US $\$ 158.00$ in the USA, Canada, and Mexico; UK £96.00 + VAT elsewhere. Institutional subscription rates, print only: US $\$ 182.00$ in the USA, Canada, and Mexico; UK $£ 110.00+$ VAT elsewhere. Individual subscription rates, print only: US $\$ 46.00$ in the USA, Canada, and Mexico; UK $£ 26.00+$ VAT elsewhere. Correspondence concerning subscriptions should be sent to: Cambridge University Press, 32 Avenue of the Americas, New York, NY 10013-2473, USA for customers in the USA, Canada, or Mexico. Customers elsewhere should contact: Cambridge University Press, University Printing House, Shaftesbury Road, Cambridge CB2 8BS, UK.

Editorial Office: All correspondence concerning submissions and manuscripts under review should be sent to The Review of Politics, University of Notre Dame, 547 Flanner Hall, Notre Dame, IN 46556. Phone: 574-631-6623. Email: ROP.Editor.1@nd.edu. Website: www.nd.edu/ rop

Abstracting and Indexing Information: Articles in The Review of Politics are indexed in the International Index to Periodicals and the Catholic Periodicals and Literature Index; abstracted in the International Political Science Abstracts; and abstracted and indexed in ABC POL. SCI., Historical Abstracts, Social Science Index (also available in the electronic versions), Book Review Index, and International Bibliography of the Social Sciences.

Copyright (C) 2016 University of Notre Dame. All rights reserved. No part of this publication may be reproduced, in any form or by any means, electronic, photocopy, or otherwise, without permission in writing from Cambridge University Press, Rights and Permissions Manager, 32 Avenue of the Americas, New York, NY 10013-2473 USA. For further information see http://us.cambridge/org/information/rights/

Periodicals postage paid in New York, NY and additional mailing offices. Postmaster: Send address changes to The Review of Politics, Cambridge University Press, 32 Avenue of the Americas, New York, NY 10013-2473, USA.

Photocopying information for users in the U.S.A.: the Item-Fee Code for the publication (0034-6705/16 \$9.00+.10) indicates that copying for internal or personal use beyond that permitted by Sec. 107 or 108 of the U.S. Copyright Law is authorized for users duly registered with the Copyright Clearance Center (CCC) provided that the appropriate remittance of $\$ 9.00$ per article is paid directly to CCC, 222 Rosewood Drive, Danvers, MA 01923. Specific written permission must be obtained for all other copying. 